\title{
ENTRE MIRADAS, PALABRAS Y TRADICIONES
}

\section{Between Glances, Words and Traditions}

\author{
Jesús Morales Bermúdez*
}

DOI: http://dx.doi.org/10.29043/liminar.v19i2.863

A

1 trazar las primeras líneas de esta presentación, se agolpan en la mente pensamientos, ideas, quietud también, en torno a cuanto constituya el cuerpo palpitante de las humanidades y los estudios humanísticos, cierta aura. Es de evocar al poeta T. S. Eliot en su evocación a Heráclito, íncipit de sus prodigiosos "Cuatro cuartetos": "aunque el logos es común a todos, la mayoría de los hombres vive como si cada cual tuviese su particular entendimiento". El logos, la palabra, herencia común a los seres humanos, ha recorrido sinuosos laberintos en pos de su modélica construcción; no una, sin embargo. El hombre y su medio, según experiencia de Herder, extienden, como en la mesa de naipes, variedad casi ilimitada, comprensible, tal se tratase de ser "uno y el mismo", "uno y múltiple", en voz de Heráclito. En las múltiples formas del ser, música, pintura, poesía, han sido precursoras de formas sistemáticas de conocimiento, y lo siguen siendo. Ellas mismas son formas de conocimiento en formulaciones igualmente sistemáticas o, mejor, orgánicas en su libertad, por lo mismo, con exigencias de concentración, de atención precisa. La naturaleza de ellas, diferenciada de la especulación pura en tanto convoca a la sensibilidad, a la sensualidad, las emociones, a las zonas oscuras del ser, condujo desde muy pronto, desde Platón por lo menos, desde los elohistas en otra tradición, a la crítica, cuando no a la desconfianza hacia ella, a su desdén: rostro de la afirmación nueva de la razón y, en momento paritario, de la ciencia. El estudio de Freud, desde Foster, en su "Tótem y tabú", propone esa necesidad de eliminar al padre para alcanzar completa autoafirmación (Freud, 1991), existencia, "en sí" diría Kant. Mas, los trazos de una necesaria bifurcación hubieron progresión desde temprano tiempo, Platón, claro, Vico, las tradiciones cifradas de la cábala, los prontos estudios de textos bíblicos y textos clásicos como basamentos para las edificaciones de sistemas de pensamiento, con toda su trayectoria de exégesis y su gemela, la hermenéutica, de tanta vitalidad a lo largo de los dos últimos siglos. Cabe la afirmación de Popper, científico de la razón: "después de todo, la ciencia no es más que una rama de la literatura" (Popper, 1982). Un como aventurar la imagen o metáfora (recurso de la literatura y las artes), de la literatura o las llamadas letras (el desciframiento) tal árbol de ramas tantas en las que florecen y maduran los frutos de la filosofía, del arte, las matemáticas, las

\footnotetext{
* Jesús Morales Bermúdez. Doctor en Antropología por la Escuela Nacional de Antropología e Historia, México. Investigador titular del Centro de Estudios Superiores de México y Centroamérica, de la Universidad de Ciencias y Artes de Chiapas, Mëxico. Temas de especialización: discursos literarios y artísticos, representaciones simbólicas, políticas, religiosas, de la sexualidad, la familia, el arte. Correo electrónico: memorial.87@hotmail.com.
} 
ciencias actuales y los métodos propios a cada una de esas ramas, el método científico en general. Vía atravesada por confrontaciones, sin embargo, esa discurrida por las ciencias y las humanidades, los estudios humanísticos, cuando en su emancipación las ciencias, en su novedad las ciencias sociales, en primacía, cuando no en totalidad, avistan su presencia en el espectro del conocimiento y de la humana construcción, con frecuencia sustituida esta por sociedad, sujeto, sujeto social, espectro difuso, conveniente para descentrar el humanismo y las humanas consideraciones, y arribar los estudios de la sociedad como vértice sine qua non del conocimiento moderno. Inaugurada por el Racionalismo y la Ilustración, la disputa vio pronto el arribo del Romanticismo, con sus excursos de emociones, onirismo, monstruosidades como en Hoffman y hasta ciento irracionalismo; una cauda lastrada hasta la época, presumiblemente en ciclos progresivos.

El presente número de LiminaR. Estudios Sociales y Humanísticos fue concebido como momento de encuentro de trabajos en torno a los estudios humanísticos, la literatura y las artes, desde diversos abordajes. Una particularidad puede explorarse en ellos, como esa de exponerse en diálogo imaginativo al adentrarse en lo lábil de las "cuestiones fronterizas", espectro este más o menos amplio, habida cuenta de la consistencia intramuros de cada vertiente disciplinaria y sus especificidades. Dentro de dichas cuestiones se sitúan las lateralidades de origen de las humanidades, de los estudios humanos en general y el origen de las ciencias desde ellos, la novedad de ciertos debates de las disciplinas contemporáneas, la circunstancia de bordes geográficos donde se disecciona una misma lengua, se multiplica, se modifica; las maneras formales de abordar los temas de siempre de la literatura, las artes, las humanidades; los temas del ser humano, el mundano e histórico ser humano, en las mil máscaras de la "novedad"; como escribiera Schopenhauer: la novedad de la muerte, el amor, los sueños, el origen, el fin. El tan impulso por la novedad, el interés en ella, bien desde los ejercicios de creación, desde la invención, la innovación científica o del pensamiento, han sido parte de la historia, vis a vis de fruslerías, sin merma por ello del ahínco humano generación tras generación: con cada generación, con cada ser humano pareciera emerger el mundo de nuevo y, ciertamente, ser concebido como nuevo, cuánto más las expresiones de él en lienzos, escrituras, simbolizaciones y hasta rituales. También el afán de los estudiosos se renueva, si bien intentan ellos tender puentes y fundar tradiciones o fortalecerlas, a gusto con los enfoques inaugurales de sus propias trayectorias. Cada recepción es también nueva, veta inagotable, vivificante del placer y del conocimiento. Acercamientos a partes de tradiciones propias a los estudios humanísticos se dan cita en este número, especie de invitación a gustar cuestiones añejas abordadas con instrumentos intelectuales nuevos, miradas. En este camino...

El texto de Martin Lienhard, "El pensamiento humano y sus materializaciones", se adentra, de manera brillante, erudita y clara, en los terrenos de esas cuestiones fronterizas en que se mece la palabra escrita, la literatura, en particular el tránsito de la oralidad y su vivacidad hacia la vivacidad de la tumba de la voz, la escritura, como reflexionara Walter Ong (1990) al atraer la frase del escriturista: "la letra mata pero el espíritu vivifica" (2 Cor. 3,6). La vivacidad de la palabra en voz, la oralidad, y los vericuetos por donde transitan imaginerías culturales y sus simbolizaciones, han atraído desde años los afanes de Lienhard; han atraído desde arcano, a los estudiosos de tradiciones escritas y a algunos antropólogos del siglo XIX por lo menos, a novelistas singulares como Walter Scott, a estudiosos de esa vertiente conocida como "historia oral". Los estudios literarios en general, aquellos relativos a la crítica textual e interpretación, exégesis y hermenéutica, ven su origen en la larga tradición de conocer la formulación y significados de los textos primordiales, homéricos y bíblicos. Lo enuncia someramente Lienhard en este trabajo pero toma distancia, quizás porque en momento anterior se aventurara en las sendas gráficas de aquella oralidad, desde la también aventura de escritores abrevantes de sus fuentes para el curso de sus escritos, en dos latitudes de "nuestra América", resultado expuesto en su asombroso libro La vozy su huella (1990).

Pero, "la voz" parece no darle reposo doquiera Lienhard se asome, como en los testimonios de esclavos 
negros o en grupos humanos de América y latitudes de su conocimiento. La voz, hálito alado e insomne, confiere también aliento a las puestas en escena teatrales o cinematográficas e, igual, desde estas últimas punza las nervaduras de Lienhard, quien se adentra en su transitoriedad, bien como cinéfilo, bien como director de cine. Quién dijera que pneuma e imago fueran apoyo para algunas de sus exploraciones. Se detiene, pues, en la oralidad, pero en otros sistemas de comunicación, la gestualidad, la música vocal, la danza, en los cuales podría rastrearse el ímpetu humano, esa necesidad humana de hacerse visible el movimiento y hacer visible su movimiento. No es insulso el que las vanguardias artísticas abrevaran de esos sistemas. De nueva cuenta, como en el Romanticismo, prestigiar algo de los mundos ocultos por la Modernidad en su afirmarse en la razón ilustrada.

En "El pensamiento humano y sus materializaciones", habiendo enunciado la tradición de estudio de textos primordiales, el autor se aviene a una mirada positivista, en borde con el Romanticismo, a partir de Jean-Jacques Rousseau, de autores contemporáneos y particularmente de Leroi-Gourhan, cuya concepción de "la pareja fonación-grafismo... de muy diversa naturaleza”, sugiere a Lienhard proponer un tránsito no exclusivo de la oralidad a la escritura sino de formas aleatorias de lo oral a estampas en movimiento, como ocurre en el cine contemporáneo. A partir de su largo conocimiento de las culturas andinas y mesoamericanas, particularmente, pero de las africanas y brasileiras; de su ejercicio de director de cine, se adentra en poemas orales, en mitos y mitografías, en pinturas primordiales y en lienzos precolombinos, en las lecturas de especialistas sobre ellos, para construir un entramado reflexivo e invitar a hacer más complejo aún el campo de los estudios acerca de los orígenes de la literatura y las artes. Desde la mediación del cine, cada vez más explorado como recurso para el estudio de obras artísticas, musicales y literarias sobre todo, se amplía el horizonte de mirada para comprender "la huella" de la oralidad y los relatos. Algún esbozo discursivo sobre alguna huella gráfica haya alcanzado algún epigrafista o arqueólogo desde una pequeña pieza mesoamericana en piedra. Una estatuilla con glifos, pocos glifos, sirviera, por ejemplo, a Piña Chan para, considerar de ella un como misal o libro de oraciones o guía a descifrar por el ritualista en su ejercicio. Estatuilla en mano, mirar la secuencia gráfica, los glifos y su discurso guiar: "Señor de campos verdes, el viento no llegue, las lluvias en cambio sí, no tantas para no aguachinar las siembras..., buena cosecha nos esperes..., y tú, dale su posol a la Señora de la tierra que está con su vientre abierto y tiene sed...". La curiosidad de Lienhard, nuestro autor, ensancha, también, nuestra curiosidad y nuestro conocimiento de sociedades de oralidad, pero de la oralidad misma y sus formas de vida, de mutación. El trabajo destaca, además, por la precisión en su construcción, formal, metódica, lingüísticamente, en su versatilidad de diálogo con autoridades en la materia atraidos por el autor del texto, este mismo de primer nivel.

En similar diapasón de interés, el estudioso Enrique Flores ofrece su trabajo "Zamé o la utopía", trabajo de alta especialización en tanto recurre a los ejercicios literarios o filosóficos de autores inscritos, en su mayoría, en el marco de la razón ilustrada, si bien de diferentes siglos, mas no necesariamente con relaciones entre sí, o concordancias, como no sea la propuesta por el autor del trabajo, ciertamente original y provocativa. Con el propósito de engarzar sus voces en un diálogo, Enrique Flores lleva a cabo un ensayo creativo, a la manera de un ejercicio teatral. Salen a escena actores aparentemente discímbolos, concordantes en la construcción del autor, y pulsan la lira de sus modulaciones históricas, filosóficas, teológicas, jurídicas, en torno a asuntos sustanciales de la civilización. El Marqués de Sade, Denis Diderot, Bartolomé de Las Casas y, aún, el novelista paraguayo Augusto Roa Bastos, extienden la baraja de sus consideraciones en torno a la civilización y el salvajismo, con la disección de formas de relación social, propiedad, matrimonio y familia, sexualidad, incesto, la perseverancia del deseo en uno de sus, afeitados o sin afeites, rostros: la crueldad.

Hay un encantamiento en el autor, propiciado por huellas de oralidad y de "complejidad semiótica e intercultural de lengua y de traducción", apreciable en partes de los escritos de su interés, no por ello 
frágiles, cuanto de hondura en sus implicaciones. Permite ponderar momentos per-formativos, traslación de humanidad y de actitudes, lábiles, entre lo primitivo original y lo filosófico con hibridación por colonización. Un margen, también, de enunciación en el trabajo, esa tensión colonial, des colonial; como los polos de inocencia por paridad de sexo y género o de perversión por predominio de masculino sobre femenino; pervivencia, en autores, de exotismo hacia el buen salvaje, contracara de ambigüedad hacia lo propio. En semejante espejo, el contraste entre reglas sociales y morales con las manifestaciones culturales y sus prácticas, incluidas la antropofagia y otras formas de crueldad, en la crueldad sibarítica de los propios relatos, acaso en sus autores. El ejercicio literario, antropológico, crítico de Enrique Flores, se engalana con su diálogo acucioso con la obra de Marqués de Sade, Diderot y Las Casas, pero con Roa Bastos, con nodos particulares de Freud y Lacan, Derrida, Lévi-Strauss, con quienes ofrece al lector la puerta hacia un igual diálogo creativo exigente de erudición.

Aquello enunciado por Enrique Flores, relativo a "los polos de inocencia por paridad de sexo y género o de perversión por predominio de masculino sobre femenino", una derivación histórica sujeta a regulaciones de diferente naturaleza, ha dado cauce a movimientos reivindicativos de larga trayectoria. La segunda mitad del siglo XX, luego de las dos guerras mundiales, vivió el auge de la llamada liberación sexual, con sus expresiones de mayor liberalidad en países europeos y los Estados Unidos de Norteamérica. Tampoco fenómeno inédito. En términos teóricos, Alexandra Kolontay brindó ejemplo; en el ejercicio vital, otras latitudes. El asunto del amor, en su conjunción de libertad y poesía o arte en general, ciñe las inquietudes de las escritoras abordadas por Felipe Sánchez Reyes en su artículo "La liberación sexual del nuevo siglo XX, a través de las escritoras francesas". La pintora mexicana Nahui Olin, en París a principios del siglo pasado, y las escritoras francesas Colette y Renée Vivien construyen, cada quien desde su circunstancia, miradas frescas y nuevas en torno a su ser mujer y sentirse mujer, en torno a sus sexualidades y las maneras de concebirlas, de vivirlas, distantes de la práctica aún des-emancipada de su época. En este texto, el autor dibuja una mirada, entrañable y crítica, desde los escritos relativos, sitúa el rango humano y social de cada una de las escritoras, los impactos alcanzados por sus escritos y vidas, la impronta en las entrañas de la sociedad francesa de principios de siglo XX, en los albores de su notable transformación, de tamaño impacto en latitudes del mundo. Entre los méritos del artículo, solventemente leve en su erudición, no menor resulta ese de entrelazar las obras de estas mujeres y el perfil de su actuar con personajes de la pintura ( simbolista, modernista) y de la literatura señeras, tal la Nora de Casa de muñecas de Henrik Ibsen. Cada cual de estas mujeres de excepción es, en su ser y, a la vez, en el personaje edificado desde sí misma, a la vez de saberse personaje, el gran teatro del mundo, al cual surcan desde su modosismo y se erigen como precursoras de "la liberación sexual y social que se desarrollará en la década de los sesenta a nivel mundial". También de los vigorosos movimientos actuales en reivindicación de las preferencias y las diferencias.

Si abrimos el compás de consideraciones de preferencias y diferencias, podemos topar con la incomprensión y hasta la intolerancia, aún entre pares, donde se yerguen los muros del conmigo o contra mí, planteados por la polarización de supuestas verdades políticas; muy particularmente en su expresión extrema de represión o de confrontación violenta. Entre pensadores, por mucho de ponderar la reflexión kantiana de deslindar credo y conocimiento, en su artículo "¿Qué es la Ilustración?" (1781), no deja de primar la íntima necesidad de una especie de confesionalidad hacia la asumida como expresión de razón histórica. Es frecuente, sin embargo, la muestra de personalidades en quienes el silencio es quilate superior al del foro, Sócrates uno de ellos, al final de su vida. El artículo "Las lecciones del silencio: María Zambrano y José Gaos ante José Ortega y Gasset", de Roberto Sánchez Benítez, retrae para nosotros el hecho, considerado como ominoso, de esa especie de contradicción entre el pensar y el actuar del maestro de España, José Ortega y Gasset, en el marco de la Guerra Civil. Particularmente María Zambrano, discípula dilecta, anhelaba, casi exigía, una expresión pública de 
Ortega en favor de la República. Y el silencio de Ortega la exasperaba. Casi similar el anhelo de Gaos. En ambos discípulos cae el velo de la distancia hacia el maestro y la perseverante necesidad de entender su silencio, su sentido. El texto de Sánchez Benítez, texto de un conocedor, devela de manera progresiva la conciencia en Ortega del fracaso del intelectual en la época moderna, la primacía de la masa y la de sus operarios, cuestión revisada, luego de él, por Elias Canetti. La centralidad, en la época moderna, de esta cuestión preconizada por Ortega como cuestión igualmente central de su pensamiento, difiere la necesidad de nuevas palabras, reiteración y, antes bien, el fulgor de su silencio, no necesariamente comprensible, como no medie experiencia similar de entendimiento.

Precisamente, cierto nivel de entendimiento o comprensión alcanzaron Zambrano y Gaos al cabo de los años y de reflexión en torno a su maestro, expresado en el concepto de un silencio profético. El recurso explicativo hacia esa dimensión profética se inscribe en la tradición de "El profeta", poema de Pushkin, y en las cuitas de pensadores de entreguerras, quienes sitúan el hecho profético en una dimensión secular, hasta nuestros días, como en Dietrich Bonhoeffer, quien dijera: "la Iglesia permanecía muda, cuando debía haber gritado...", en el ascenso nazi y, obrando en consecuencia, llegó a adherirse a la resistencia contra Hitler, acto de total silencio, y morir ahorcado. Es, de acuerdo con su propia reflexión, ser parte de una vocación político social para restaurar la dignidad humana y, como en el caso de Jeremías el profeta, llegar a ser "un hombre sin pueblo" y no poder más hablar por su pueblo, ni a su pueblo, ni llorar con su pueblo (Jer. 16, 3-7). Ortega había pre-visto al interior de sí, como en premonición, en memoria, la explosión hispana de guerra civil, predijo de ella, pero, a diferencia de Jeremías, por ejemplo, no permaneció en su patria: emprendió el destierro, el reiterar ser "un hombre sin pueblo", sin asidero, signo de arranque de la posmodernidad. Una especie de exceso de conocimiento al cual no podía sino seguir el silencio, o pasar a la acción. En su caso, habiendo escrito en sus Meditaciones del Quijote, hombre de silencio: "Entre las varias actividades de amor solo hay una que pueda yo pretender contagiar a los demás: el afán de comprensión", no le aguardaba sino el silencio.

El autor del artículo, Roberto Sánchez Benítez, al recorrer los textos de Ortega, los de Gaos y Zambrano, al reflexionarlos desde la novedad de su mirada personal, extiende un dilatado diálogo de pares filósofos transterrados, no exento diálogo de rispideces y reclamos, llevado a cabo primordialmente en América Latina, para la propia comprensión latinoamericana y la de sus huéspedes, exiliados republicanos. Según la reflexión de los filósofos desde los inicios del pensamiento: el ser, la conciencia del ser, y el ser para la polis. En ambos polos se inscriben el pensamiento, la conciencia, la filosofía. Lo dijo el propio Ortega: "El hombre rinde el máximum de su capacidad cuando adquiere la plena conciencia de sus circunstancias. Por ellas comunica con el universo. iLa circunstancia! iCircum-stantia! iLas cosas mudas que están en nuestro próximo derredor! Muy cerca, muy cerca de nosotros levantan sus tácitas fisonomías con un gesto de humildad y de anhelo, como menesterosas de que aceptemos su ofrenda y a la par avergonzadas por la simplicidad aparente de su donativo".

La dimensión social y secular campea el aura del siglo XX, florecen en América Latina movimientos libertarios de diversa índole: políticos, educativos, literarios, artísticos. El siglo XIX había ahondado las semillas de voces latinoamericanas en el concierto internacional, comenzando con el modernismo de Darío y sus congéneres. Mas el Modernismo adquirió rostros en cada país sudamericano, particularidades y tiempos. En ese universo emerge, como flor radiante, particularmente radiante, en tanto se sitúa en la contracara del orden establecido y sus estéticas, la pintora Débora Arango. Precisamente, el modernismo en la pintura, el simbolismo, el muralismo, la búsqueda de emancipación de formas dadas de las cuales es preciso escapar en pos de deletrear de nueva manera la realidad y el arte, se erige como el haz que impulsa a la artista colombiana objeto del artículo "Develando el caos: Débora Arango, la artista y su obra, desde la perspectiva de Cornelius Castoriadis", de Jaime A. Gómez Prada. Desde la pasión por comprender a la artista y el país colombiano, pasión también de ella como persona, sin 
menoscabo de su ambición artística de expresar al ser humano, Gómez Prada recorre la trayectoria pictórica de Débora Arango, con sus acodos en Medellín, México, Madrid y sus incursiones en los temas paisajísticos, del cuerpo humano, en general figurativos, y cómo la artista experimenta la necesidad de dotar ese cuerpo y su contexto de la particularidad con que se mueve en el caos contemporáneo extraído de su mirada, una mirada en el despojo de afectaciones y afeites, en la sintonía de ser en el mundo de los pesares del hombre. Sin demérito de su confesionalidad religiosa o, mejor, como consecuencia de ella, la pintora asume el despojo como heredad y expone en su pintura la desnudez de Eva en el cruento paraíso de su cotidiana normalidad. Gómez Prada se vale de la guía reflexiva del filósofo Cornelius Castoriadis para, desde el afincar de este en la tradición ontológica, considerar los tonos estéticos de la obra de Débora Arango, los quiebres en esa obra, el suspenso de su particularidad, en el cual suspenso se mece el alma, como bien anhelaba Platón, como a fin de cuentas se mece y se impone en las consideraciones críticas de la actualidad. La grandeza de un cosmos, surcado del caos social y estético de Colombia y América Latina se patina en la obra de esta artista. Pudo Gómez Prada caminar sin tanto engarce castoridiano, pero ese camino es también de emancipación de formas dadas, en los tiempos dados, a la manera de la vía sinuosa seguida por la pintora objeto de su estudio.

Cada camino, como el de la pintora del artículo anterior, implica transposiciones geográficas, humanas, de entendimiento. Otras transposiciones las hay. Una de ellas es la transposición de fronteras geográficas y simbólicas. De esas fronteras y sus cuestiones se ocupa también este número; no por ellas mismas, por sus particularidades expresivas, en lo humano, en lo lingüístico, social, estético, mágico. En particular, la frontera sur de México existe de manera reciente en la ocupación de estudiosos, si se considera el largo tiempo de estudio de la frontera norte. Por lo general, se la ha abordado desde ámbitos arqueológicos, etnográficos, políticos, de movilidad religiosa y humana, vía sucesos migratorios, como también da cuenta el artículo. Existen menos miradas de corte literario, humanístico, artístico y de ese perenne encuentro familiar, emotivo, comercial, peregrino de santuarios compartidos por quienes existen como región fronteriza. También de formación de familias transnacionales, como estudió la antropóloga Alcalá Moya.

Movido por un acto de recepción hermenéutica, Carlos Gutiérrez Alfonzo, en su artículo "Encuentros en un espacio geográfico: antropología y literatura”, como pez en el agua de ambas disciplinas, antropología y literatura, gusta de ir en pos de novedades en el abordaje de su materia, con un enfoque particular de la frontera entre México y Guatemala. Se sitúa desde la literatura, si bien con reflexión antropológica, hacia la definición de una antropología de la literatura en la frontera, es decir, cómo formula la literatura las similitudes y diferencias culturales entre México y Guatemala. Le favorece haber la presencia de autores, no por leídos ponderados en trabajos otros, como son los casos de Rosario Castellanos y su Balún Canán, o Alfonso Reyes. Al decidirse el autor por una exposición no exenta de aire coloquial, sin por ello restarle "seriedad académica", el artículo da cuenta, entre otras cuestiones, de avances en una aventura de conocimiento de la cual han sido parte múltiples instituciones académicas de la región y siguen siéndolo. "Encuentros en un espacio geográfico: antropología y literatura" aparece como un texto develante de cuánto se haya planteado y encontrado antes, cuánto ahora, qué des-lumbra el trabajo en su apartado medular y en su propósito de centrar dos disciplinas en sí mismas distantes de ser puestas en juego por las actuales ciencias sociales en la región, mas imprescindibles para el conocimiento del ser bogante, aparte de, en sus ríos, en las pasiones de su andar en pos de ideales del espíritu y de la materia.

El peso de mujeres en la literatura y las artes, en general, adquiere consistencia, cuando alcanzan buen hacer en la consideración de sus críticos. Es el ejemplo planteado por Norma Angélica Cuevas Velasco en su artículo "Frontera de sal', engarce para un tríptico de la identidad migrante en la narrativa de Nadia Villafuerte". En dicho artículo, la autora se aviene a favorecer una lectura particular de tres obras de Nadia Villafuerte, escritora chiapaneca. A Cuevas Velasco le importa 
desentrañar eso explícito de su postulado: "los modos de subjetivación de los personajes migrantes" en los cuentos y novela de la escritora. Motivo privilegiado de sus escritos hasta hoy, la migración y las secuelas propias a ese fenómeno humano, trama el camino de la chiapaneca en su escritura y lo camina, cual de su propia migración se tratase, y despliega el pliego de una geografía especularmente real y especularmente otra. En esa geografía se adentra Cuevas Velasco para, más allá de los relatos de migración contenidos en ella, acercarse a la subjetivación de quienes la llevan a cabo, "descentrado, enunciado desde su memoria fragmentada”, trasluz de la propuesta del crítico peruano Antonio Cornejo Polar. Se vale, la autora, en un primer momento, de recorrer las características propias a la generación de la escritora y la discusión perdurable del sentido de generación, de las peculiaridades poéticas precedentes y actuales, una dimensión migrante en ese sentido, a la par de fronteriza. La autora da forma a un tríptico, constituido por las obras "Frontera de sal", Barcos en Houston y Por el lado salvaje de Nadia Villafuerte y lo descifra. Ofrece al lector de su artículo, a la crítica literaria misma, el aire fresco de lo sórdido como motivo estético en su encuentro con "la belleza de la transgresión". La galería de personajes en el "tríptico" de la escritora chiapaneca cobra nitidez en el artículo de Norma Angélica Cuevas Velasco, los vuelve a ellos entrañables, sin parar mientes en su degradada condición; pondera, además, los méritos estéticos y de poética en la obra, lleva a cabo un ejercicio de crítica lúcido, amable de la literatura, honra para la crítica misma.

Ejercicio diferente de crítica, desde la dimensión fronteriza demarcada por la literatura y lo fantástico, el artículo favorecido por Teresa García Díaz, "Ajenidad, desarraigo y necesidad de pertenencia en La invasión del pueblo del espíritu de Juan Pablo Villalobos", explora la circunstancia radicalmente migrante del ser humano, cierta inasibilidad y errancia en la estructura de su ser, según se expresa en una novela del escritor mexicano Juan Pablo Villalobos, habitante de Barcelona, considerando dimensiones de espacio y tiempo. Ambas dimensiones posibilitan, en la novela y en el artículo, la percepción de pertenencia a nada, el efugio del terrenal hábitat y sus significados, la permanente afirmación de la individualidad, su confirmación. El texto exige una dilatada atención por adentrarse en los sentidos de su estructura, de su propuesta, derivados del insuficiente conocimiento de las novelas de Villalobos, por lo menos por quien escribe estas líneas.

Al inicio de las presentes notas se daba cuenta de un interés, en autores, por llegar a la novedad en ciertos debates de las disciplinas contemporáneas. Puede también ocurrir el procurar novedad a debates de tiempos pretéritos bajo el actual cobijo de circunstancias intelectuales, culturales, de política cultural, bonancibles, difíciles en el pretérito tiempo. La circunstancia de bordes geográficos donde se disecciona una misma lengua, decíamos atrás, las maneras formales de abordar los temas del ser humano, del mundano e histórico ser humano en la literatura, aparece en este artículo de Rodrigo García de la Sienra “El 'divino mestizo' frente a la máquina de guerra. Mimesis heterogénea y subjetividad migrante en El tiempo principia en Xibalbá, de Luis de Lión". Desde su nominación, el artículo se adentra en los nodos debatibles de heterogeneidad, etnoficción, literatura indígena e indigenista y los debate. Recorre algunas de las consideraciones numinosas en torno al Popol Vuh y recurre a cuidadosa crítica de fuentes y crítica textual. Lleva a cabo una también cuidadosa lectura del texto novela El tiempo principia en Xibalbá, del escritor guatemalteco Luis de Lion, desaparecido en los entretelones del largo conflicto armado en el centroamericano país. La estructura, lenguaje, consistencia del texto, las múltiples críticas en torno a él, brindan a De la Sienra la arena propicia para plantear una mirada utópica, la de Luis de Lion en la novela dirá, en superación de las consideraciones de mestizajes, hacia la impronta de nominaciones nacionales afincadas en la precolombina época, nominaciones, por otra parte, aupadas por actuales élites en nada precolombinas, no por ello en negación de los universos utópicos.

La conjunción de textos humanísticos, médula de esta entrega de LiminaR, cerraría en este espacio, como no fuera por el sobresaliente siguiente texto, colocado en la revista como "documento". De un documento vivo y vivificante se trata, inscrito en el hoy de sentido. Una cuestión fronteriza, difuminada por fusión de 
los bordes disciplinarios, según interés del autor, se encuentra en el trabajo "Tamales para la embajada", de Carlos Navarrete Cáceres. Ejercicio de oralidad viva, como habría querido el movimiento surrealista y, antes, la esforzada estética de civilizaciones. Habría la oralidad de este texto fenecido dada la naturaleza instantánea de su ser, como no fuera por la dedicación del autor para contenerla en notas, entrevistas, en un primer momento; en su memoria, luego; en la voluntad de urdirle una existencia escritural, a la vez amorosa y libre. Trabajador él mismo de ensayos y monografías antropológicas, a la par de ser figura indiscutible de la arqueología mesoamericana, con no escasa frecuencia ha dado a luz libros y ensayos en que la pasión antropológica halla fusión con la creación literaria, deriva ella desde El banquete de Platón o los Salmos de David y Salomón. Carlos Navarrete ha dado a la luz obras de creación, en el lenguaje llano de la región central de Chiapas, desde algún personaje popular, atrayendo a la palabra escrita, tumba de la oralidad, la variedad de emociones del ser humano, con una mirada tierna y plagada de humor. Nada en el ser humano es insignificante, pareciera decirnos.

"Tamales para la embajada", el texto documento de Carlos Navarrete Cáceres, pudo ser articulado por su autor, sirviéndose de las voces, conversaciones, entrevistas, cual de una cimbra para edificar un edificio verbal. En cambio de ello, hubo la voluntad de insuflar las voces, vivas ellas, para desde ellas comunicar sinos, destinos, alegrías, tragedias, en contextos precisos de guerra y paz, de transposición de fronteras geográficas, políticas y simbólicas, hacia la dimensión platónica de banquete y su encuentro con lo humano. Más allá de brindar explicaciones o buscarlas, siempre ellas provisionales, puso en juego el autor sus capacidades y sensibilidad hacia una modalidad de comprensión, como anhelara Wittgenstein, y urdiera el relato de una mujer, y desde esa particular mujer, desplazamiento hermenéutico dijera Gadamer, sus dejos de cosmovisión y lengua regionales. La lengua regional guarda acodos de significación en pos de los cuales el autor brinda un para-texto acaso innecesario si tan solo, como lectores, en pos de recepción hermenéutica, nos viéremos movidos y del gusto de las formas populares del habla, máscaras tantas donde se emboza la vivacidad de las lenguas.

Dejos con el documento referido tiene el artículo "Quedarse en el pueblo: arraigo y solidaridades familiares en el Soconusco (Chiapas, México)" de Alicia Rinaldy. Sugerente título, contracara de la movilidad de quienes migran. Y no porque no ocurran transposiciones de lugar y hasta desarraigos entre los miembros de cada familia: los hay, pero importa el estudio de lo local y cómo eso local se formula y re-formula. Llevado a cabo, el artículo, a partir de entrevistas con hombres y mujeres, e historias de vida, en el ejido Paraíso del Soconusco, la autora ocupa las palabras de sus entrevistados para urdir una reflexión en torno a las formas de vida familiar en dos momentos, el de cierto auge agrícola, del café, y el paso a la economía mundial. Se interesa por el papel jugado por los hombres y aquel jugado por las mujeres, sustancia de la solidaridad familiar, con los cambios en la sociedad. Sensible a esos cambios, la autora pondera cuánto para las mujeres la trayectoria de sus vidas parte de la formada con su matrimonio y no con la de su origen, acaso común en los hombres. "En la intimidad de las familias, la división sexual no ocurre exclusivamente en relación con las tareas domésticas, sino también con el conocimiento genealógico, que es un reflejo y una extensión de las mismas", dice. Sugerente, el artículo de Alicia Rinaldy favorece una mirada etnográfica con posibilidad de comparación con la vida ejidal en otras latitudes de Chiapas, como la selva Lacandona, donde pueden notarse, también, los tránsitos de época, de comportamientos, de formas de desarrollo.

Y adentrados en la antropología y en el estudio de lo local, el artículo de Francisco J. Fernández-Repetto y Mariana Guevara-Rosado, “Agentes locales en la construcción de la imagen turística del Pueblo Mágico de Izamal, iproductores o reproductores?", coloca frente al lector el valor de las imágenes: el concepto "imagen turística" y sus relaciones con la mirada turística y la autenticidad; los componentes de la imagen turística; los discursos y prácticas en relación con la imagen turística promovida; el intento de comprensión de la 
imagen turística, plantean los autores. Todo ello, relativo al caso de los guías de turistas en Izamal, Yucatán. En las últimas décadas asistimos al auge mediático y de políticas públicas relacionadas con el turismo. Hacer de este sector un motor de desarrollo económico y social es boga en el país, con inversiones estatales y federales de distinto rango. En torno suyo se mueven autoridades de los tres niveles, operadores turísticos nacionales e internacionales, organismos gremiales de hoteleros, restauranteros, comerciantes..., una policromía de ciudadanos esperanzados. Dentro de tal policromía, figuran los guías de turistas, con formación o improvisados, con la grandeza de espíritu para ofrecer informaciones culturales supuestamente verdaderas o auténticas. Los autores se adentran en los debates contemporáneos acerca de los consumos culturales, la oferta performativa, mercadeo turístico, contenidos de valor de los destinos turísticos, etcétera. Puede el lector adentrarse en una experiencia particular, la de Izamal, en Yucatán, y desde esa experiencia mirar con inocencia y encanto o sin inocencia y encanto la cadena de prácticas comunes a destinos turísticos del país, trátese de pueblos mágicos, ciudades patrimoniales, rutas de conventos o gastronómicas, centros ecoturísticos.

No abunda la presentación en cada uno de los otros artículos del número. Cada uno de ellos cuenta con acercamientos antropológicos y refiere a experiencias concretas, a casos concretos, con los respectivos enfoques teóricos y la puesta en escena de las reflexiones de sus autores. Por ejemplo, "Gestión de riesgos y estrategias comunitarias ante los desastres en localidades de la Región Istmo-Costa en Chiapas", de César Aramis Martínez Leina, Guadalupe del Carmen Álvarez Gordillo y Elisa Cruz Rueda, enfoca su mirada en el asunto concreto de la percepción del riesgo, los conflictos sociales que se derivan de ellos y las estrategias comunitarias para superarlos. De peso igualmente contemporáneo en la lucha social de las mujeres, particularmente, el artículo "La interrupción legal del embarazo y el activismo del siglo XXI en Chiapas", de Alma Alejandra Soberano Serrano, pondera el protagonismo de las mujeres, organizadas o independientes, y sus maneras de enfrentar respuestas institucionales y de política pública.
Dos textos referidos a asuntos más concretos aún, cierran el número, antes de las reseñas de rigor: primero, el artículo "La biblioterapia en un grupo de mujeres en situación de violencia: fundamentos conceptuales y balance de intervención", de Magda Ivette Moreno Morales y Homero Ávila Landa, ejercicio claro de tendencias actuales hacia la reflexión-acción, en el caso valorando las posibilidades del libro, de suyo un objeto de goce, pero como apoyo en las vías de resolución anímica en mujeres en situación de violencia. Finalmente, "Celebración metropolitana del Día de Muertos. Comunalización/comunidad, migración, memoria festiva y resistencia en Buenos Aires y Santiago", de Pablo Mardones y Francisca Fernández, sitúa al lector ante la mirada fresca de los autores en el texto, con suma de enfoques en sugerencia de complejidades frente al abordaje de festividades populares, como la del Día de Muertos, sus formas de tránsito de medios rurales a urbanos, sus maneras de hacerse simbólicas en los nuevos espacios.

El presente número de LiminaR comba su sentido humanístico, su perseverante amor por las artes, con las fotografías del entrañable colega Efraín Ascencio Cedillo, sociólogo de formación, artista de la lente por la pasión irrefrenable de su interior. Proveniente de Jalisco, halló arraigo en Chiapas y, como versa el decir en Chiapas, "aquí se halló”: vocación y destino. Se cuenta él entre los fundadores del Centro de Estudios Superiores de México y Centroamérica y de la muy prestigiada revista LiminaR. Estudios Sociales y Humanísticos, a cuyo primer número favoreció con la imagen gráfica y a toda una colección de ella. La Señora del Alba le llamó al oído, precisamente al alba, un 23 de septiembre del año 2020. La esperaba, según premoción suya, en la entrevista video "Sensibilidad de la luz. Efraín Ascencio Cedillo. Fotógrafo", de Patricia de la Fuente Castro, Yuri Tekpatzin López Pérez, Karen Liliana Pérez Martínez. Con La Señora del Alba fue, con el vacío en los corazones de sus amigos. Una nota, necesaria para enmarcar las fotografías de este número y la trayectoria poética de Ascencio Cedillo, también como homenaje de sus compañeros y de quien esto traza, la escribió el colega Martín de la Cruz López Moya, la fechó en esta 
ciudad, el 1 de diciembre de 2020 y la nominó "Efraín Ascencio Cedillo. Polinizador de visualidades y el arte de las tramas urbanas". Versa de la siguiente manera:

\section{La fotografía es inquietante, suspicaz;} es una aventura jubilosa que puede conducir a la desmesura de epifanías insólitas o a la acritud yerta en el transcurrir diario de la intimidad o en el de la convulsa sociedad. Efraín Ascencio Cedillo

Así como aparecen las cosas que no estaban y el sol las deja ver desde el amanecer, Efraín con su luz y su diario caminar nos ha dejado un legado para contemplar la diversidad de mundos posibles que él imaginó, junto con su cómplice, su cámara fotográfica, su más íntima. Efraín fue el Ojo de San Cristóbal de Las Casas, donde vivió durante casi tres décadas. Situó a su querida ciudad bajo la mirada de la clonación cultural, desde sus claroscuros, de sus múltiples encuentros y desencuentros; de sus maneras diversas de vivirla y habitarla. Lo sabía muy bien, a la ciudad se la lee con los pies y con todos los sentidos. Al andar por sus calles, con su cámara, extensión de sus ojos, lucidez de todo su ser, quedaron sus huellas plasmadas en imágenes que hacían posible contemplar la belleza de su intuición de esos instantes que se hicieron eternos. Andar a la deriva para sorprenderse en cada acto cotidiano de la ritualidad urbana y ser interpelado para registrar el paisaje y el vocerío de la ciudad. Andar errante en la calle entre el juego de luces de días y noches.

Hay una interrelación íntima entre el artista y la ciudad, entre Efraín y San Cristóbal de Las Casas. Con su mirada lúcida, de imágenes llena de contenidos sobre la ciudad en su multiplicidad de mundos coexistentes, ahí se entraman rostros y objetos que estaban ocultos, alegrías y resistencias, sabores y sonidos, momentos festivos. La ciudad, con sus espacios habitados y sus narrativas visuales, fue cómplice de su inspiración.

Fueron muchos los géneros fotográficos los que experimentó, si bien estaba consciente, como Peter Burke, que: "los fotógrafos, como los historiadores, no ofrecen un reflejo de la realidad sino representaciones de la misma". El documental etnográfico, foto periodismo, fotografía conceptual y abstracta, de la analógica a la digital, de retrato, erótica, arqueológica, de paisaje, en blanco y negro; con temas muy variados, momentos de algarabía colectiva, de resistencias y protestas sociales, de la intimidad de los objetos de su casa, de sus seres familiares más íntimos en Guadalajara y en el rancho La Rana, en Arandas, Jalisco.

Efraín nació el Día de los Músicos, por eso buena parte de su producción fotográfica fue sobre lo musical en sus diversas manifestaciones. Él estaría destinado a ser un músico, en su variante de melómano, con escucha y mirada oblicua de sonoridades infinitas. Aunque siempre reconoció que sus preferencias musicales fueron el blues, el rock y el jazz, y en ocasiones, cierta música vernácula, aquella que se producía en los Altos de Jalisco, donde en su seno familiar tuvo sus primeras experiencias con la música en vivo. Su melomanía nos mostró su gran sensibilidad por las imágenes audio visuales de una diversidad de ocasiones musicales y que trascendían sus afectos o preferencias, fueran músicas tradicionales, de alabanza, electrónicas, de las juventudes o las que se presumen como las más íntimas.

En su caminar incesante por las calles, Efraín experimentó el ritual de la seducción que se establece entre ojo que mira, la cámara y el sujeto o el objeto retratado. Pude observarlo en ese ritual de dialogo y seducción. Sus registros fueron en muchos de los espacios cotidianos, en especial, en momentos de movilización social, carnavalescos, momentos festivos, de protesta o resistencia social; de la ritualidad urbana, de la calle, del transeúnte o de las huellas humanas dejadas en las paredes de la ciudad que ha sido tatuada.

En más de una ocasión, con Efraín nos confiamos de muchas formas nuestras divagaciones sobre lo que significa narrarse a sí mismo con una identidad, de ese anhelo por sentirse parte de una colectividad con un ethos compartido y no solo ser imaginado como un transeúnte errante. Por esas incertidumbres, cuando recién llegó a San Cristóbal le seducía indagar sobre las identidades barriales, del barrio de Guadalupe en 
especial, donde nunca se cansó de caminar. Es que no podía asumirse de un lugar o con un referente en particular; no era ni de aquí ni de allá o, quizás llevaba consigo un poquito de todo, era de Jalisco pero también chiapaneco porque hablaba de "vos"; antropólogo pero también artista; roquero pero también adherente a muchas otras músicas; güero de rancho y afrodescendiente, como el mismo se asumía; de cultura campirana y también urbana, sus botas marca Establo contrastaban con su vestir como urbanita; no se adhería a alguna ideología en particular pero sí crítico de cualquier tipo de excesos; no era religioso pero si espiritual; aliado del silencio pero estruendoso con sus imágenes y sus ideas; era un gran maestro pero también un gran alumno, siempre estuvo ávido de nuevos aprendizajes, y así.., sucesivamente. Por eso su afán por representar las múltiples alteridades que se encontraba en su diario caminar; salir de sí para encontrarse con los Otros. Pero también para experimentar ese sentido de pertenencia y, no dudo, que lo encontró en San Cristóbal, donde transitó entre diversas comunidades de sentido.

Donde Efraín se vio con mayor identificación fue con los Fotógrafos Independientes. Tragameluz, espacio de encuentro, de promoción, educación y creación de las artes fotográficas fue su comunidad de sentido por convicción, elección y vocación. Desde Tragameluz se transformó en el encaminador de las almas de muchos otros fotógrafos, algunos incursionaban en el mundo de la fotografía y otros ya contaban con experiencia comprobada. Ambos fueron sus amigos a quienes les inspiró amistad, admiración y respeto. Desde ahí participó en la construcción de los territorios de la fotografía en la ciudad: Canthil 4 , Café Bresson, Punto ciego, Laboratorio audiovisual de investigación social y experimentación, por mencionar solo algunos. Territorialidades que se extendieron por los laberintos de la ciudad imaginada, material y virtual, con sus célebres exposiciones fotográficas: "La fuga de Eros", "A la merced de Tata Lampo", "Estas no son fotos de viaje" o, su serie "Obsesiones nómadas"; lo mismo que en cursos, talleres, libros, revistas, carteles o en su cuenta de Facebook. Junto con otros fotógrafos visitantes o residentes, con sus exposiciones en espacios no tan convencionales como cantinas, mercados o calles de las periferias, propició un cruce de diálogos visuales polivalentes, crónicas de lo cotidiano de una ciudad polifónica como es San Cristóbal de Las Casas.

Con su partida la ciudad lloró, pero también se iluminó con las creaciones de otros artistas: pintores, fotógrafos, músicos, escritores y personas de otros oficios, amigos todos de Efraín. Vinieron más amigos para encontrarse, sus imágenes se multiplicaron, es que sigue siendo un portal de encuentros para la imaginación, la amistad y la generosidad.

Martín de la Cruz López Moya

El recorrido ha intentado abrir la página al presente número de nuestra revista LiminaR. Estudios Sociales y Humanísticos; ha intentado extender sobre el mantel muestras de los platillos a ser degustados por el lector. Vale la pena probarlos, más allá de las limitaciones de quien los extiende. En todo caso, la invitación: iGustad!

\section{Referencias}

Freud, Sigmund (1991). "Tótem y Tabú". En Obras completas, t. 13. Buenos Aires: Amorrortu, pp. 7-163.

Lienhard, Martin (1990). La vozy su huella: escrituray conflicto étnico-social en América Latina (1492-1988). La Habana: Casa de las Américas.

Ong, Walter J. (1990). Oralidad y escritura. Tecnologías de la palabra. México: Fondo de Cultura Económica.

Popper, Karl (1982). El conocimiento objetivo. Un enfoque evolucionista. Madrid: Tecnos. 